\title{
DEVELOPMENT OF INTERACTIVE LEARNING MEDIA LECTORA INSPIRE ON BASIC BANKING SUBJECT TO IMPROVE STUDENT'S LEARNING INTEREST
}

\author{
PENGEMBANGAN MEDIA PEMBELAJARAN INTERAKTIF LECTORA INSPIRE \\ PADA MATA PELAJARAN DASAR-DASAR PERBANKAN UNTUK MENINGKATKAN \\ MINAT BELAJAR SISWA
}

By:

Pratiwi Apriniya

Accounting Education Study Program Yogyakarta State University pratiwi.apriniya2015@student.uny.ac.id

Mimin Nur Aisyah

Lecturer in Accounting Education Department Yogyakarta State University mimin_nuraisyah@uny.ac.id

\begin{abstract}
This research aimed to develop interactive learning media with Lectora Inspire for the students of grade $X$ AKL SMK Negeri 1 Tempel on Basic Banking subjects with the competence of saving. The research used the Research Development with ADDIE (analysis, design, development, implementation, evaluation) model. The media was assessed by material expert, media expert, and teacher. The results show that the feasibility of interactive learning media by material expert in strongly feasible category (average score of 4, 26), by media experts in strongly feasible category (average score of 4,36), by teacher in strongly feasible (average score of 4,33), and by students in feasible category (average score of 4, 07). The interactive learning media developed is strongly feasible to be used as learning media for students. The student's learning interest before and after the use of interactive learning media has increased by $8 \%$ from $64 \%$ to $72 \%$. Paired sample t-test obtained $t_{\text {count }}-5.213$ with sig 0.000 showed significant learning interest's improvement. Therefore, it can be concluded that interactive learning media is able to improve student's learning interest.
\end{abstract}

Keywords: Interactive Learning Media, Lectora Inspire, Student's Learning Interest.

\section{Abstrak}

Penelitian ini bertujuan untuk mengembangkan media pembelajaran interaktif dengan Lectora Inspire untuk siswa kelas X AKL SMK Negeri 1 Tempel dengan kompetensi simpanan tabungan pada mata pelajaran Dasar-Dasar Perbankan. Penelitian menggunakan metode penelitian dan pengembangan dengan model ADDIE. Media pembelajaran dinilai kelayakannya oleh ahli materi, ahli media, dan guru. Hasil penelitian menunjukkan bahwa kelayakan media pembelajaran interaktif pada mata pelajaran Dasar-Dasar Perbankan oleh ahli materi yaitu dalam kategori sangat layak (skor rata-rata 4,26), oleh ahli media yaitu dalam kategori sangat layak (skor rata-rata 4,36), oleh guru dalam kategori sangat layak (skor rata-rata 4,33), dan oleh siswa dalam kategori layak (skor rata-rata 4,07). Oleh karena itu, media pembelajaran interaktif yang dikembangkan sangat layak digunakan sebagai media pembelajaran untuk siswa. Minat belajar siswa sebelum dan sesudah penggunaan media mengalami peningkatan sebesar $8 \%$ dari $64 \%$ menjadi $72 \%$. Pada paired sample t-test didapat $t$ hitung -5,213 dengan sig. 0,000 yang menunjukkan signifikansinya peningkatan 
minat. Dengan demikian, dapat disimpulkan bahwa media pembelajaran interaktif yang dikembangkan dapat meningkatkan minat belajar siswa

Kata Kunci: Media Pembelajaran Interaktif, Lectora Inspire, Minat Belajar Siswa.

\section{INTRODUCTION}

Education is the most important factor in human character building. It is also one of instruments in forming people either to be good or bad. Therefore, the government is very serious about education because a good education system will support the quality of future generation especially on their adaptability skills.

We need to know that the curriculum in UU No. 20 Tahun 2003 is a set of plans and arrangements concerning the objectives, content, and materials as well as how to use it as a guide for learning activities to achieve the education goals. In curriculum 2013, the learning process is designed in a simple and attractive method to enhance student's learning interest. The student's learning interest is an essential point in the fruitfulness of learning. Students who have a high interest in learning will be able to follow the learning process well. The teachers are also need to be more creative in developing the lesson plans and conducting teaching activities in order to enhance student's learning interest.

Interest is "a feeling of like and attraction with something without being comprehensive" (Djaali, 2006: 121). Interest is in people themselves. The great interest is an important asset to achieve the goal. Slameto (2003: 180) explains that interest can be expressed through statements. It is able to show students' interest in something which can also be manifested through their participation in activities. Students who have an interest in a certain subject, they will tend to give a great attention in the learning process.

Based on the interview which was conducted to the students of class X SMK N 1 Tempel, students' learning interest are still low in learning Basic Banking subject. The students were bored and less interested in teacher's teaching method who always asked the students to summarize the materials which are already provided in the books. The other problem was the teacher often left the classroom during learning process, especially when it was only theory. Therefore, the students tended to be passive and found it difficult to learn. Students expected the teacher to be more creative in the lesson. The good learning process will increase the student's learning interest.

One of the factors in improving student's learning interest is the methods used in the learning process. The teacher needs a good skill to achieve an effective and efficient learning. Sri Widiastuti (2010: 49) explains that skill is "the ability to operate a work easily and closely". Hamzah (2008: 130) suggests that skill is the ability to do the tasks that are related with physical and mental. The teacher's skills in transfering knowledge are important to achieve the objective of learning. In formal education there are components that support teacher's teaching skills such as curriculum, school facilities, and etc. The use of these components in formal education can support the teaching skills in order to fluent, directional, and in accordance with the learning objectives. Teaching skill can be supported by the media of technology that continue to develop now days.

The development of technology is able to ease students' and teacher's activities. As an educator, the utilization of technology is required to support in learning process. However, most teachers are not using the technology provided in the school. They need to be encouraged to use the technology to develop a learning media so that it will increase the student's learning interest. 
Based on observations in SMK N 1 Tempel on February 26, 2018, there are sufficient technology supports in school such as LCD projector, internet connection, and computer lab for accounting. Sufficient facilities should ease the teacher in learning process. However, students were asked to summarize the materials which are already in the book and they were also asked to look for other references on internet by phone. The teacher explained the materials with traditional method without using any media. The teacher did not use the learning media properly on Basic Banking subject. It made the students tended to speak with their friends who caused the classroom became less conducive. Learning will be more fun when it is supported by the learning media, especially using the technology to enhance the student's learning interest.

Learning media is a school facility that can improve the quality of education in the learning process. The use of creative and innovative media will increase interest in learning and achievements as well as the students' ability to learn actively. The presence of learning media will help students in receiving material presented as it can be used in school and outside of the school.

Learning media is "media used as something that can transmit messages and can stimulate the mind, feelings, attention, and students' ability, so it can encourage of occurrence of an intentional learning process, aims, and controlled" (Yusuf Hadi Miarso (2004: 458)). Darmawan (2012: 51) also presents that the media is a tool of messages delivery between teachers and students by utilizing electronic media through the subjects that are programmed into the system. So, the media developed must be packaged attractively to stimulate students in learning. Technology-based learning media will attract students to pay attention to the material and increase their interest in learning. Interesting learning system will make it easier for students to achieve learning objectives.
Based on the interview with Basic Banking subject teacher, the teacher was rarely used creative and innovative learning media. The teacher applied the students centered learning model and students were asked to learn independently. In addition, teacher used the traditional method in learning, she will explain the material if there are students asked. The media used by the teacher was limited to PowerPoint Presentation with little frequency of use. Lack utilization of media is one of the main problems of teacher in teaching. Limited knowledge and skills of teacher in developing media are the main factors of which teacher rarely uses learning media. Therefore, the researcher will develop a media that is highly readable, interactive, and able to encourage student's active learning.

The learning media in this research was developed using the Lectora Inspire application. Lectora Inspire is software that can be used to create interactive learning media and one alternative that can attract student's learning interest. Lectora Inspire application can be helpful in preparing materials or presentations. The strength of Lectora Inspire is user-friendly or easy to use. Lectora Inspire doesn't require internet connection, because the output can be opened and saved in computer or laptop. In addition, the features on Lectora Inspire such as Snagit, Camtasia, and Flypaper can be used to develop the media based on the needs.

Lectora Inspire application selected with the consideration that it has not yet been introduced and used in SMK $\mathrm{N} 1$ Tempel. The interactive learning mediabased Lectora Inspire was intended to make students easy in learning and understanding the material presented. In addition, it is expected to guide students in the utilization of technology which will increase the student's learning interest. Diah Rahmawati (2016) stated that learning media based Lectora Inspire is worthy for learning. It is able to enhance the student's learning 
interest and more effective than learning using PowerPoint and book.

The materials to be developed on the learning media is Basic Banking subject. The Basic Banking subject is part of the subjects in Accounting Program. Based on the interview, students have difficulty in understanding the material. Attractive learning media are needed to facilitate students to understand the material. Therefore, researchers provide solutions by developing interactive learning media based Lectora Inspire on Basic Banking subject for students.

\section{RESEARCH METHOD Type of Research}

This research used the Research and Development $(\mathrm{RnD})$ method. This method is aimed to produce or develop a product. Research and development method is a research method used to produce a specific product and test the effectiveness or feasibility of such product (Sugiyono, 2012: 407). This study used a ADDIE model developed by Dick and Carey. ADDIE model consists of 5 (five) stages namely analysis, design, development, implementation, and evaluation.

\section{The Subject and Object of Research}

The subjects in this research were material expert and media expert from lectures of Accounting Education Program, learning practitioner (teacher) and students of class X AKL 2 in SMK N 1 Tempel. The objects in this research were the feasibility of interactive learning media using Lectora Inspire and student's learning interest.

\section{Place and Time}

Test study was conducted at SMK N 1 Tempel on Jl. Magelang $\mathrm{Km} \mathrm{17,}$ Margorejo, Tempel, Sleman, Daerah Istimewa Yogyakarta. The research was carried out from February to March 2019.

\section{Procedure Development}

This research used ADDIE model developed by Dick and Carry to design a learning system (Endang Multiyaningsih, 2012: 200). ADDIE model consists of analysis, design, development, implementation, and evaluation. The following is the description of development Lectora Inspire interactive media:

1. Analysis Stage

This stage consisted of analysis of the curriculum, analysis of the students' needs, and analysis of the students' characteristics.

2. Design Stage

The researcher made a design of the learning media such as storyboard, material, questions, answer, background, picture, and back sound.

3. Development Stage

At this stage, the process of developing the media is carried out by Lectora Inspire. The product was then validated by material expert, media expert, and teacher.

4. Implementation Stage

This stage included product tests for student in small group trial and field trial. Small group trial from class of $\mathrm{X}$ AKL 1 and 3 SMK N 1 Tempel consisted of 12 students (each of 6 students). Field trial from class of $\mathrm{X}$ AKL 2 SMK $N 1$ Tempel consisted of 30 students.

5. Evaluation Stage

At this stage the researcher measured the feasibility of interactive learning media and the improvement of student's learning interest.

\section{Types of Data and Data Collection Techniques}

Types data collected in this research included quantitative and qualitative data. Data collection techniques used the questionnaires, syllabus and lesson plan (RPP).

\section{Research Instrument}

Instruments in this research were non-test instrument. The instruments are media validation instrument and student's learning interest instrument. Media 
validation instrument were filled by material expert, media expert, teacher, and students.

The questionnaire of student's learning interest was filled by student. The instrument included 20 statements. The instrument was analyzed using validity test and reliability test.

1. Validity Test

Validity test used the Product Moment formula from Pearson which is:

$$
\begin{aligned}
& \mathrm{r}_{X Y}=\frac{n \sum X Y-(\Sigma X)[\Sigma Y)}{\sqrt{\sqrt{\left[n \Sigma X^{2}-(\Sigma X)^{2}\right]\left[n \Sigma Y^{2}-[\Sigma Y)^{2}\right]}}} \\
& r_{X Y}: \text { Correlation coefficient } \\
& \mathrm{X}: \text { Score per item } \\
& \mathrm{Y}: \text { Total score per item } \\
& \mathrm{n}: \text { Total respondent }
\end{aligned}
$$$$
\text { (Rostina Sundayana, 2014: 60) }
$$

2. Reliability Test

Reliability test using the Cronbach's Alpha formula, as follows:

$$
\begin{aligned}
& r_{11}=\left(\frac{k}{k-1}\right)\left(1-\frac{\Sigma \sigma_{b}^{2}}{\sigma_{t}^{2}}\right) \\
\boldsymbol{r}_{11} & : \text { reliability } \\
\boldsymbol{k} & : \text { number of item } \\
\sum \sigma_{b}^{2} & : \text { the number of variance item } \\
\sigma_{t}^{2} & : \text { total varians }
\end{aligned}
$$

(Rostina Sundayana, 2014: 69)

\section{Data Analysis Techniques}

The data analysis in the research was concluded as follows:

1. Media Feasibility Data

a. Change the qualitative data into quantitative data.

b. Calculate the average score of aspect with the following formula:

$$
\bar{X}=\frac{\Sigma X}{N}
$$

$$
\begin{array}{ll}
\bar{X} & =\text { Average score } \\
\mathrm{N} & =\text { Item subject } \\
\Sigma X & =\text { Total score }
\end{array}
$$

(Ermawati \& Sukardiyono, 2017:207)

c. Change average score into a qualitative value criteria as follows:
Table 1. Converting Quantitative Data to Qualitative Data

\begin{tabular}{|c|c|l|}
\hline No & Score & \multicolumn{1}{c|}{ Category } \\
\hline 1 & $>4,2 \mathrm{~s} / \mathrm{d} 5,0$ & Strongly Feasible \\
\hline 2 & $>3,4 \mathrm{~s} / \mathrm{d} 4,2$ & Feasible \\
\hline 3 & $>2,6 \mathrm{~s} / \mathrm{d} 3,4$ & Moderately Feasible \\
\hline 4 & $>1,8 \mathrm{~s} / \mathrm{d} 2,6$ & Not feasible \\
\hline 5 & $1,0 \mathrm{~s} / \mathrm{d} 1,8$ & Strongly Not feasible \\
\hline
\end{tabular}
Source: (Eko Putro W, 2016: 112)

2. Improvement of Student's Learning Interest

The next step is calculating the percentage of interest in learning. The steps were as follows:

a. Analyze quantitative data descriptively with criteria scoring.

b. Calculate the score for each of the aspects of interest in learning.

c. Calculate the score of the student's learning interest for each aspect with the following formula:

Percentage of interest score: $\frac{\text { interest score }}{\text { max score interest }} \times 100 \%$

(Ermawati \& Sukardiyono, 2017:207)

d. The next step is tested with the formula t-test paired samples.

Researcher used paired samples to find out whether the learning media can improve the student's learning interest. The formula is as follows:

$$
t=\frac{\bar{D}}{\left(\frac{S D}{\sqrt{N}}\right)}
$$

D : The average margin of 2 scores

SD : Standard Deviation

$\mathrm{N} \quad$ : Total Pairs

(Nana Danapriatna dan Rony Setiawan, 2005: 108-110)

\section{RESULT AND DISCUSSION \\ Result}

This study used an ADDIE model. ADDIE model consist of 5 (five) stages namely analysis, design, development, implementation, and evaluation.

1. Analysis

At this stage, researcher has observed in class $\mathrm{X}$ AKL 2 and interviewed an 
accounting teacher of SMK $\mathrm{N} 1$ Tempel. Observation and interview were done on February 26, 2018. These activities were aimed to find out the needs of learning media development for students. Based on the observation, the analysis stage consisted of needs analysis, curriculum analysis, and student's characteristics analysis. The results of the learning observation and interview with the teacher of Class $\mathrm{X}$ AKL SMK N 1 Tempel showed that the students only have one kind of course book and they strongly depend on it. Moreover, teacher used limited media such as PowerPoint and it was rarely used in learning process. The teacher often used conventional teaching in the learning process. The student's learning interest on Basic Banking subject was still low. It was found that most students talked to their classmates and did not paid attention to the learning. It made classroom situation become ineffective. The materials used in developing media is saving as it was considered to be difficult by the students based on the analysis, researcher tried to develop an interactive learning media using Lectora Inspire to help teacher and student in learning process.

2. Design

At this stage, the researcher made a media design by collecting information which supported the developing of learning media such as the creation of storyboards, the preparation of material, the questions and answers, background, picture, and back sound. The concept of learning media is an interactive module that consist of a material, questions and evaluation in the topic of Saving.

3. Development

This stage is a process of developing the learning media by using Lectora Inspire. This media consisted of instruction, competence, material, test, reference, and profile. It was conducted through two stages of validation. The first validation was conducted by material and media experts and the second validation was carried out by the teacher. The revisions were made based on the advices and opinions by the experts. The preface of final product is displayed below:

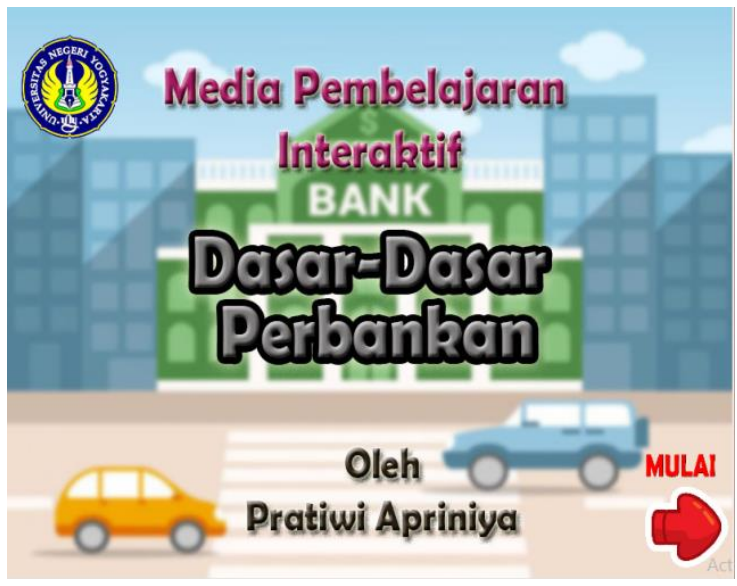

Figure 1. Display Preface Page

In summary, a recapitulation of validation was presented in the following table:

a. Validation by Material Expert

Table 2. Recapitulation of Validation Result by Material Expert

\begin{tabular}{|l|l|l|l|l|}
\hline No & $\begin{array}{l}\text { Feasibility } \\
\text { Aspect }\end{array}$ & Score & $\begin{array}{l}\text { Ave- } \\
\text { rage }\end{array}$ & $\begin{array}{c}\text { Cate- } \\
\text { gory }\end{array}$ \\
\hline 1 & $\begin{array}{l}\text { The } \\
\text { Syllabus }\end{array}$ & 7 & 3,5 & Feasible \\
\hline 2 & $\begin{array}{l}\text { The Quality } \\
\text { of Material }\end{array}$ & 22 & 4,4 & $\begin{array}{l}\text { Strongly } \\
\text { Feasible }\end{array}$ \\
\hline 3 & $\begin{array}{l}\text { The } \\
\text { Presentation } \\
\text { of Material }\end{array}$ & 39 & 4,88 & $\begin{array}{l}\text { Strongly } \\
\text { Feasible }\end{array}$ \\
\hline & Total & 68 & 4,26 & $\begin{array}{l}\text { Strongly } \\
\text { Feasible }\end{array}$ \\
\hline
\end{tabular}

Based on table 2, the material expert assessed the feasibility of media from the aspect of the syllabus, the quality of material, and the presentation of material and provided the score of 3,5 (Feasible), 4,4 (Strongly Feasible), and 4,88 (Strongly Feasible). The average score of feasibility aspect is 4,26 (Strongly Feasible). 
b. Validation by Media Expert

Table 3. Recapitulation of Validation Result by Media Expert

\begin{tabular}{|l|l|l|l|l|}
\hline No & $\begin{array}{l}\text { Feasibility } \\
\text { Aspect }\end{array}$ & Score & $\begin{array}{l}\text { Ave- } \\
\text { rage }\end{array}$ & Category \\
\hline 1 & $\begin{array}{l}\text { The } \\
\text { Benefit of } \\
\text { Media }\end{array}$ & 13 & 4,33 & $\begin{array}{l}\text { Strongly } \\
\text { Feasible }\end{array}$ \\
\hline 2 & $\begin{array}{l}\text { The } \\
\text { Design of } \\
\text { Media }\end{array}$ & 34 & 4,25 & $\begin{array}{l}\text { Strongly } \\
\text { Feasible }\end{array}$ \\
\hline 3 & $\begin{array}{l}\text { The } \\
\text { Operation } \\
\text { of Media }\end{array}$ & 18 & 4,5 & $\begin{array}{l}\text { Strongly } \\
\text { Feasible }\end{array}$ \\
\hline \multicolumn{2}{|l|}{ Total } & 65 & 4,36 & $\begin{array}{l}\text { Strongly } \\
\text { Feasible }\end{array}$ \\
\hline
\end{tabular}

Based on table 3 , the media expert assessed the feasibility of media from the aspect of the benefit of media, the design of media, the operation of media and provided the score of 4,33 (Strongly Feasible), 4,25 (Strongly Feasible), and 4,5 (Strongly Feasible). The average score of feasibility aspects is 4,36 (Strongly Feasible).

c. Validation by Teacher

Table 4. Recapitulation of Validation Result by Teacher

\begin{tabular}{|c|c|c|c|c|}
\hline No & $\begin{array}{c}\text { Feasibility } \\
\text { Aspect }\end{array}$ & Score & $\begin{array}{l}\text { Ave- } \\
\text { rage }\end{array}$ & Category \\
\hline 1 & $\begin{array}{l}\text { The Benefit of } \\
\text { Media }\end{array}$ & 13 & 4,33 & $\begin{array}{l}\text { Strongly } \\
\text { Feasible }\end{array}$ \\
\hline 2 & $\begin{array}{ll}\text { The Design } \\
\text { Media }\end{array}$ & 22 & 3,67 & Feasible \\
\hline 3 & $\begin{array}{l}\text { The Operation } \\
\text { of Media }\end{array}$ & 16 & 4 & Feasible \\
\hline 4 & The Syllabus & 10 & 5 & $\begin{array}{l}\text { Strongly } \\
\text { Feasible }\end{array}$ \\
\hline 5 & $\begin{array}{l}\text { The Quality of } \\
\text { Material }\end{array}$ & 21 & 4,2 & $\begin{array}{l}\text { Strongly } \\
\text { Feasible }\end{array}$ \\
\hline 6 & $\begin{array}{l}\text { The } \\
\text { Presentation of } \\
\text { Material }\end{array}$ & 24 & 4,8 & $\begin{array}{l}\text { Strongly } \\
\text { Feasible }\end{array}$ \\
\hline \multicolumn{2}{|c|}{ Total } & 106 & 4,33 & $\begin{array}{l}\text { Strongly } \\
\text { Feasible }\end{array}$ \\
\hline
\end{tabular}

Based on table 4, the teacher assessed the feasibility of media from the aspect of the benefit of media, the design of media, the operation of media, the syllabus, the quality of material, and the presentation of material and provided the score of 4,33 (Strongly Feasible), 3,67 (Strongly Feasible), 4 (Strongly Feasible), 5 (strongly Feasible), 4,2 (Strongly Feasible), and 4,8 (Strongly Feasible) for each. The average score of feasibility aspect is 4,33 (Strongly Feasible).

4. Implementation

The implementation was carried out in two small groups trials of 6 students per group and field trial on 30 students which were divided into 8 groups and 4 to 5 students per group. In implementation process, the students used learning media and were asked to fill out the questionnaire to give their judgments and opinion towards the multimedia. The following are the results of students' assessment tests:

Table 5. Recapitulation of Feasibility Result of Small Group Trial

\begin{tabular}{|l|l|c|c|l|}
\hline No & $\begin{array}{l}\text { Feasibility } \\
\text { Aspect }\end{array}$ & Score & $\begin{array}{l}\text { Ave- } \\
\text { rage }\end{array}$ & Category \\
\hline 1 & $\begin{array}{l}\text { The Benefit } \\
\text { of Media }\end{array}$ & 159 & 4,42 & $\begin{array}{l}\text { Strongly } \\
\text { Feasible }\end{array}$ \\
\hline 2 & $\begin{array}{l}\text { The Design } \\
\text { of Media }\end{array}$ & 248 & 4,13 & Feasible \\
\hline 3 & $\begin{array}{l}\text { The } \\
\text { Operation of } \\
\text { Media }\end{array}$ & 100 & 4,17 & Feasible \\
\hline 4 & $\begin{array}{l}\text { The } \\
\text { Syllabus }\end{array}$ & 107 & 4,46 & $\begin{array}{l}\text { Strongly } \\
\text { Feasible }\end{array}$ \\
\hline 5 & $\begin{array}{l}\text { The } \\
\text { Presentation } \\
\text { of Material }\end{array}$ & 150 & 4,17 & Feasible \\
\hline \multicolumn{2}{|l|}{ Total Average } & 764 & 4,27 & $\begin{array}{l}\text { Strongly } \\
\text { Feasible }\end{array}$ \\
\hline
\end{tabular}

Based on table 5, the student assessed the feasibility of media from the aspect of the benefit of media, the 
design of media, the operation of media, the syllabus, and the presentation of material and provide the score of 4,42 (Strongly Feasible), 4,13 (Strongly Feasible), 4,17 (Feasible), 4,46 (Strongly Feasible), and 4,17 (Feasible) for each. The average score of feasibility aspects is 4,27 (Strongly Feasible).

Table 6. Recapitulation of Feasibility Result of Field Trial

\begin{tabular}{|c|c|c|c|c|}
\hline No & $\begin{array}{l}\text { Feasibility } \\
\text { Aspect }\end{array}$ & Score & $\begin{array}{l}\text { Ave- } \\
\text { rage }\end{array}$ & Category \\
\hline 1 & $\begin{array}{l}\text { The Benefit of } \\
\text { Media }\end{array}$ & 362 & 4,02 & Feasible \\
\hline 2 & $\begin{array}{l}\text { The Design of } \\
\text { Media }\end{array}$ & 616 & 4,11 & Feasible \\
\hline 3 & $\begin{array}{l}\text { The Operation } \\
\text { of Media }\end{array}$ & 257 & 4,28 & $\begin{array}{l}\text { Strongly } \\
\text { Feasible }\end{array}$ \\
\hline 4 & The Syllabus & 231 & 3,85 & Feasible \\
\hline 5 & $\begin{array}{l}\text { The } \\
\text { Presentation } \\
\text { of Material }\end{array}$ & 367 & 4,08 & Feasible \\
\hline \multicolumn{2}{|c|}{ Total Average } & 1833 & 4,07 & Feasible \\
\hline
\end{tabular}

Based on table 6 , the student assessed the feasibility of media from the aspect of the benefit of media, the design of media, the operation of media, the syllabus, and the presentation of material and provide the score of 4,42 (Strongly Feasible), 4,13 (Strongly Feasible), 4,17 (Feasible), 4,46 (Strongly Feasible), and 4,17 (Feasible) for each. The average score of feasibility aspects is 4,07 (Feasible).
5. Evaluation

Evaluation stages held to know the responses of student's learning interest. At this stage, questionnaire about learning interest was used. It was measured by Likert scale. The questionnaire consisted of 20 questions with 17 positive statements and 3 negative statements. The differences of students' interest learning after they were taught using the learning media can be seen as follow:

Table 7. Recapitulation of Student's Learning Interest

\begin{tabular}{|c|c|c|c|c|c|}
\hline \multirow[t]{2}{*}{ Indicator } & \multicolumn{2}{|c|}{ Before } & \multicolumn{2}{|c|}{ After } & \multirow{2}{*}{$\begin{array}{c}\text { Improve- } \\
\text { ment \% }\end{array}$} \\
\hline & Total & $\%$ & Total & $\%$ & \\
\hline $\begin{array}{l}\text { Feeling } \\
\text { good to } \\
\text { learn }\end{array}$ & 301 & 58,79 & 340 & 66 & 7,21 \\
\hline $\begin{array}{l}\text { Attention } \\
\text { in learning }\end{array}$ & 352 & 69 & 387 & 76 & 7 \\
\hline $\begin{array}{l}\text { Interest in } \\
\text { learning }\end{array}$ & 283 & 55 & 362 & 71 & 16 \\
\hline $\begin{array}{l}\text { Award in } \\
\text { learning }\end{array}$ & 351 & 69 & 380 & 74 & 5 \\
\hline $\begin{array}{l}\text { Awareness } \\
\text { of the } \\
\text { benefit of } \\
\text { learning }\end{array}$ & 360 & 70 & 372 & 73 & 3 \\
\hline Total & 1647 & 64 & 1841 & 72 & 8 \\
\hline
\end{tabular}

Based on table 7 above, it can be concluded that the interactive learning media is able to increase students' learning interest with an increase of $8 \%$ from $64 \%$ to $72 \%$. There is the results paired samples T-Test:

\begin{tabular}{|c|c|c|c|c|c|c|}
\hline & \multicolumn{2}{|c|}{ Mean } & Correlation & Sig. & T & Sig. (2-tailed) \\
\cline { 2 - 7 } & Before & After & & & & \\
\hline $\begin{array}{c}\text { Pair } \\
1\end{array}$ & 51,4688 & 57,5313 & 0,917 & 0,000 & - & 0,000 \\
\hline
\end{tabular}

The result of paired samples t-test table showed that the average value of initial learning interest score was 51.4688 while the final learning interest was 57.5313. The paired sample t-test table showed a correlation number of 0.917 with sig. 0,000 .
It means that there is a significant difference between total interest before and after learning process using the media. 
Discussion

1. Development of Interactive Learning Media

This research and development procedure is developed using ADDIE model namely analysis, design, development, implementation, and evaluation.

2. Feasibility of Interactive Learning Media

The feasibility of interactive learning media is examined through validation by material experts, media experts, and learning practitioners (teacher). The material expert is a lecturer of Accounting Program at UNY. Material expert validation is used to find out the feasibility study based on media in terms of the material presented. Validation from material expert obtained an average of 4.26 in the category of "Strongly Feasible". The advice revision by material expert are (1) the achievement indicators of competence should be gradually reached $\mathrm{C} 4,(2)$ Give an example of a product from a bank and Given the separation of the amount of savings withdrawals at the teller and at the ATM, and (3) The text is thickened or italicized.

Media expert is a lecturer of Accounting Program. Results Validation is performed to find out the feasibility aspect consisted of the benefits of media, design, and operation of the media. Validations from media expert obtain an average of 4.36 in the category of "Strongly Feasible". The advice revision by media expert are (1) the font size on the preface is minimized or adjusted, (2) give a different coloring between the title and the subtitle, (3) use a consistent size and type of writing, (4) add the 'back' navigatio button in the test page, and (5) use the same transition
Practitioner of learning is the Basic Banking subject teacher of SMK N 1 Tempel. Validation from teacher was carried out to find out the feasibility of aspects related to material and media developed in interactive learning media. Validation from teacher obtained an average score of 4.33 in the category of "Strongly Feasible". Teacher did not provide any comments over the learning media.

Students as the subject of this research are 30 students from class $\mathrm{X}$ AKL 2 SMK Negeri 1 Tempel. The results of the field trial consisted of the benefit of the media, design, operation of the media, the syllabus, and the presentation of material. Validation of students through field trial obtained an average score of 4.07 with categorized as "Feasible". Therefore, the interactive learning media Lectora Inspire strongly feasible use as learning media for student.

3. The Improvement of Student's Learning Interest

Based on the questionnaire results as seen on table 19, the student's learning interest after they were taught using the interactive learning media was increased. Test results showed that interactive learning media are able to enhance the student's learning interest.

The five indicators were used to measure student's learning interest. The improvement is ranging from 3\% to $16 \%$ where the largest improvement is in the indicator of "interest in learning" and the smallest is in the indicator of "usefulness learning awareness". It can be concluded that the interactive learning media used in class X AKL 2 influenced the student's learning interest.

Based on the paired samples t-test result in table 20 shows that there is an improvement in student's learning interest after they were taught using 
interactive learning media. The paired samples t-test obtained $t_{\text {count }}$ is -5.213 with sig 0.000 which showed significant measurements so that the interactive learning media can increase student's learning interest.

The results of this study are in accordance with the theory stated by Azhar Arsyad (2017: 19) that the use of learning media in the teaching and learning process can generate new desires, interests, motivation, and stimulation of learning activities, and even bring psychological influences to students.

\section{CONCLUSION AND SUGGESTION Conclusion}

Based on the research results and discussion conclusions can be concluded that:

\section{Interactive Learning Media} Development Lectora Inspire through five stages:

a. Analysis stage is the initial stage which includes students' needs analysis, curriculum analysis, and students' characteristics analysis.

b. Design stage is the stage of designing products which consist of the developing of storyboards, manufacture, material, question and answer, and the buttons which are needed.

c. Development is the process of developing interactive learning media, validation by material expert, media experts, and teacher.

d. Implementation stage is a trial stage of interactive learning media for small groups' trial and field trial.

e. Evaluation is the last stage of interactive learning media development. It is aimed to measure the feasibility of learning media and increased student's learning interest.

2. The feasibility of interactive learning media is reviewed based on validation of a material expert, media experts, and teacher. The results are 4.26 (Strongly Feasible), 4.36 (Strongly Feasible), and 4.33 (Strongly Feasible) for each.

3. The responses of the students on a small group of trial obtained an average score of 4.27 (Strongly Feasible) whereas field trial obtained an average score of 4.07 (Feasible). The average score from both trials was 4.26 (Strongly Feasible).

4. Interactive Learning Media Lectora Inspire can improve student's learning interest of $8 \%$ from $64 \%$ to $72 \%$. The media learning is able to increase student's learning interest, as showed by $t$ test result of 0,917 and $t_{\text {count }}-5,213$ with sig 0,000 .

\section{Suggestion}

Based on the research results, below is the suggestions offered:

1. For School

a. School should conduct a training of media learning for teachers to enhance their teaching skills

b. School should provide sufficient accounting computer laboratory so that the classes can use them interchangeably.

\section{For Teacher}

a. Teacher should try the interactive learning media in teaching learning activities to draw students' attention and learning interest.

b. Teacher should improve their ability to develop interactive learning media.

3. For Students

a. Students should use interactive learning media for independent study anytime and anywhere.

b. Students are expected to play an active role in learning such as paying attention to the teacher, being active in asking, and discussing materials whether inside or outside the classroom. 
4. For Further Research

a. Research needs to be done with a wider range of samples and use the updated.

b. Research can be proceed with a class action research or experiments to measure the effectiveness of the use of interactive learning media.

\section{REFERENCES}

Danapriatna, Nana \& Setiawan, Rony. (2005). Pengantar Statistika. Yogyakarta: Graha Ilmu.

Darmawan, D. (2012). Pendidikan Teknologi Informasi dan Komunikasi. Bandung. PT Remaja Rosdakarya.

Eko Putro Widoyoko. (2016). Teknik Penyusunan Instrumen Penelitian. Yogyakarta: Pustaka Pelajar.

Rahmawati, Diah., Sri Witurachmi, \& Sohidin. (2016). Pengembangan Media Pembelajaran dengan Kuis Edukasi COC Berbasis Aplikasi Lectora Inspire pada Pembelajaran Akuntansi untuk Meningkatkan Minat Belajar Siswa di SMK Negeri 1 Karanganyar. Tata Arta, 2, 45-48.

Djaali. 2006. Psikologi Pendidikan. Jakarta: PT. Bumi Aksara
Mulyatiningsih, Endang. (2012). Metode Penelitian Terapan Bidang Pendidikan. Bandung: Alfabeta.

Hamzah B uno. (2008). Model pembelajaran -Menciptakan Proses Belajar Mengajar yang kreatif dan Efektif, Jakarta: Bumi Aksara.

Slameto. (2003). Belajar dan Faktor-faktor yang Mempengaruhinya. Jakarta: Rineka Cipta.

Sri Widiastuti dan Nur Rohmah Muktiani. (2010). Peningkatan Motivasi dan Keterampilan Menggiring Bola Dalam Pembelajaran Sepakbola Melalui Kucing Tikus Pada Siswa Kelas 4 SD Glagahombo 2 Tempel. Jurnal Pendidikan Jasmani Indonesia. Volume 7 Nomor 1. Hlm. 47-59.

Sundayana, Rostina. (2014). Statistika Penelitian Pendidikan. Bandung: Penerbit Alfabeta.

Sugiyono. (2012). Metode Penelitian Kuantitatif Kualitatif dan $R \& D$. Bandung: Alfabeta.

Hadi, Yusuf Miarso. (2004). Menyemai Benih Teknologi Pendidikan. Jakarta: Prenada Media. 